\title{
FINANCIAL PERFORMANCE, AUDIT DELAY AND FIRM VALUES BANKING IN INDONESIA
}

\author{
Stephanus Dwiarso Utomo, Maradewi Ayu Kumalasari, Zaky Machmuddah
}

Department of Accounting, Faculty of Economics and Business University of Dian Nuswantoro Nakula I Number 5-11 Semarang, 50131, Indonesia

\begin{tabular}{|c|c|}
\hline \multirow[b]{2}{*}{$\begin{array}{l}\text { Keywords: } \\
\text { audit delay, } \\
\text { financial perfor- } \\
\text { mance, firm value }\end{array}$} & ABSTRACT \\
\hline & $\begin{array}{l}\text { Fraud cases in capital market concerning financial report delay were the main issues of } \\
\text { the research. The aim of this research was to investigate the effect of financial perfor- } \\
\text { mance, audit delay, and firm value. Population of the research was all companies listed } \\
\text { in Indonesian Stock Exchange, from 2011-2013. The total of research samples were } 38 \\
\text { banking companies with } 97 \text { annual reports done by using purposive sampling method. }\end{array}$ \\
\hline \multirow{3}{*}{$\begin{array}{l}\text { JEL Classification: } \\
\text { G21, G32, M42 }\end{array}$} & Data analyses used were classical assumption test and hypothesis test with multiple \\
\hline & $\begin{array}{l}\text { linear regression analysis. The result of the research showed that financial performance } \\
\text { had a significant influence to audit delay, while financial performance had a significant } \\
\text { influence to firm value. Meanwhile audit delay did not significantly influence to firm } \\
\text { value. The practical implication of the research suggested the delay of the financial report's } \\
\text { delivery had an impact toward company's image in front of the stakeholders. }\end{array}$ \\
\hline & ABSTRAK \\
\hline $\begin{array}{l}\text { Kata Kunci: } \\
\text { audit delay, financial } \\
\text { performance, firm's } \\
\text { value. }\end{array}$ & $\begin{array}{l}\text { Isu utama dalam penelitian ini adalah kasus kecurangan yang terjadi di pasar modal mengenai } \\
\text { keterlambatan laporan keuangan. Tujuan dari penelitian ini adalah untuk menguji pengaruh } \\
\text { kinerja keuangan, audit delay, dan nilai perusahaan. Populasi dari penelitian ini adalah semua } \\
\text { perusahaan yang terdaftar di Bursa Efek Indonesia, dari tahun 2011-2013. Total sampel penelitian } \\
\text { sebanyak } 38 \text { perusahaan perbankan dengan } 97 \text { laporan keuangan tahunan dengan metode purpo- } \\
\text { sive sampling. Analisis data yang digunakan adalah uji asumsi klasik dan uji hipotesis dengan } \\
\text { analisis regresi linier berganda. Hasil dari penelitian menunjukkan bahwa kinerja keuangan } \\
\text { memiliki pengaruh yang signifikan terhadap audit delay, kinerja keuangan memiliki pengaruh } \\
\text { yang signifikan terhadap nilai perusahaan. Sementara audit delay tidak berpengaruh signifikan } \\
\text { terhadap nilai perusahaan. Implikasi praktis dari penelitian memberikan masukan bahwa } \\
\text { keterlambatan dalam pengiriman laporan keuangan memiliki dampak terhadap citra perusahaan } \\
\text { di depan para pemangku kepentingan. }\end{array}$ \\
\hline
\end{tabular}


The main issues in this research were cases of capital market violations handled by Bapepam-LK. Openness of issuers and public companies, securities trading and investment management were the examples of cases of alleged capital market violations handled by Bapepam-LK. Presentation of financial statements was one example of the cases related to the openness of issuers and public companies.

Based on data from the Indonesia Stock Exchange (BEI), in 2011 there were 116 listed companies that received financial penalties related to the financial statement presentation. Regulations that had been set did not make the issuers or public companies wary of it and repeatedly did delays in the delivery of financial statements. Continuing in the first half of 2012 there was still a delay in the delivery of financial statements. The data showed that 74 issuers were late in submitting financial statements. Total penalty collected because of it reached 5.49 billion rupiah.

Related to this matter, on August 1st 2012 Bapepam-LK increasingly tightened the rules by the stipulation of Decision of the Chairman of the Capital Market and Financial Institution Supervisory Agency Number 431/BL/2012 regarding the submission of annual reports of issuers or public companies that also have attachments on BapepamLK Number XK6. In addition, particularly for issuers of banks and financial institutions, Bank Indonesia (BI) had established Regulation No. 14/ 14/PBI/2012 on Transparency and Publication of Bank Reports. Nevertheless, now the supervision of capital markets, banking and financial institutions is transferred to the Financial Services Authority/ Otoritas Jasa Keuangan (OJK). Following up on late delivery of financial reporting, OJK issued Circular Letter Number 11 / SEOJK.04 / 2014 regarding Obligation of Report Submission to OJK and Regulation of Financial Services Authority Number 6/POJK.03/2015 on Transparency and Publication of Bank Report.
Circular Letter Number 11/SEOJK.04/2014 makes issuers or public companies view to deliver financial statements on time even less than the time specified. This is done to avoid administrative sanctions and suspensions in accordance with established rules. This is in accordance with Sutinen \& Kuperan (1999) explaining that the pure prevention model on regulatory compliance focuses on the certainty and severity of the sanctions. In addition to this, delivering financial statement on time even less than the time specified is useful to maintain and improve corporate image for stakeholders that are usually served as a benchmark of success in supporting the firm value for stakeholders. The delay in financial statement delivery shows that the company's financial performance is not performing well, so it will impact on the lack of stakeholders' trust and it causes investors shift their views. It results a decrease in reputation and firm value.

The financial statement aims to provide information concerning the financial position, performance, and financial position change of a company that benefit the users of financial statements in economic decision making (Statement of Financial Accounting Standards issued by Indonesian Accountants Assosiation/Ikatan Akuntan Indonesia). In order that financial statement can be useful in making economic decisions, it should be presented accurately and on time.

The information presented in financial statement is a signal submitted by the company to the stakeholders. Signal theory is rooted in pragmatic accounting theory that focuses its attention on the influence of information on user behavior change of information user. Connelly et al. (2011) reveal that signal theory is useful for describing behavior when two parties (individuals or organizations) have access to different information. The signals can be either good news information or bad news information, so the behavior of information users will change after getting the signal, especially in terms of investment decision making. 
The company will immediately inform the public if it generates profit, in this case ROA, so that audit delay will tend to be shorter. So vice versa the company will delay the announcement if the company does not make profit (losses), the audit delay is likely to be longer because the auditor will be careful in responding to it. The auditor will seek to know the cause of the loss, whether the loss is caused by a failure in the financial or by fraud done by management, therefore the auditor requires a long time to complete the audit process, and consequently it will extend the audit delay (Kartika, 2011). Further Asthana (2014) explains that the audit delay will give a bad signal for the earnings quality of that can affect the firm.

Based on the Decision Letter of the Chairman of Capital Market and Financial Institution Supervisor Agency No.43/BL/2012 on the submission of annual reports or public companies: public companies are required to submit an annual report to BAPEPAM and Financial Institution maximum four (4) months after the fiscal year ends. The annual report must include: an overview of important financial data, the commissioners board report, directors' report, company profiles, analysis and management discussion, corporate governance, corporate social responsibility, the annual financial statement that has been audited, and responsibility statement of commissioners board and directors on the truth of the annual report content.

The audited annual financial statement is one of the mandatory requirements of annual reports that should be reported by issuers or public companies. However, in making the audit report, auditor requires a relatively long time to find competent evidence. It sometimes leads to audit delay.

Delay audit is the period of completion of the financial statement annual audit, measured by the time length of the auditor's work from the book closing date to the presentation of the an- nual audit report (Lawrence \& Barry 1998), as well as Hossain \& Peter (1998) explain that the in general the audit report delay can be known from the time interval between the company's year-end financial statement and the submission date of the auditor's report. The longer the auditor needs to complete the audit work, the longer the audit delay will be and vice versa the faster the auditor needs to complete the audit work, the shorter the audit delay will be. The length and shortness of audit delay may be caused by other factors that affect. Based on previous studies there are several factors that can affect the occurrence of audit delay. One factor of them is the financial performance measured by Return on Assets (ROA).

Researches on financial performance, audit delay, and firm value have been done several times, both domestically and abroad. Up to now, researches have not had consistent results. The researches done by Ayemere \& Elijah (2015), Vuko \& Cular (2014), Lestari \& Misdiyono (2013) found evidence that the company's financial performance (ROA) has an effect on audit delay. However, Hersugondo \& Andi (2013), Kartika (2011) found different evidence, that company's financial performance (ROA) has no effect on audit delay.

In a different theme, namely regarding the financial performance (ROA) to the firm value, Gamayuni (2015), Mulyawati, et al. (2015), Hidayah (2014), and Asiri \& Hameed (2014) found evidence that financial performance (ROA) significantly affects the firm value. Different results occur in the research done by Tjandrakirana \& Monika (2014) that found evidence that the company's financial performance (ROA) has no effect on the firm value.

The above description provides an indication that research in this area is still important to do to provide a clearer theoretical picture of the relationship model between the variables above.

In general, this study aims to examine the effect of financial performance, audit delay and 
firm value. Specifically, this research aimed to: (1) analyze the effect of financial performance on audit delay; (2) to analyze the effect of financial performance on firm value; and (3) to analyze the effect of audit delay on firm value.

\section{HYPOTHESES DEVELOPMENT}

\section{The Effect of Financial Performance on Audit Delay}

Financial performance describes the success of a company that emphasizes the earnings quality. Benchmark of earnings quality can be seen from the analysis of financial ratios, one of which is ROA. ROA is the ratio between the profit/loss net generated by the company to total asset used. ROA reflects the firm's ability to generate profits from the resources (assets) it owns.

Kartika (2011) argued that companies which generate profit in this case ROA will immediately inform the public, so that audit delay will tend to be shorter. And vice versa if the company does not make profit (loss), the audit delay will tend to be longer because the company will delay the bad news information. Thus it can be interpreted that ROA affects the audit delay.

The statement is supported by Ayemere \& Elijah (2015), Vuko \& Cular (2014), Lestari \& Misdiyono (2013) who found evidence that ROA positively related to audit delay. Based on the description and empirical evidence that has been found, the hypothesis proposed is:

$\mathrm{H}_{1}$ : financial performance has significant effect on audit delay

\section{The Effect of Financial Performance on Firm Value}

Good or bad financial performance in a company can be seen from the financial statement. However, healthy or not can be seen from the company's financial performance. The earnings quality can determine the movement of stock prices. Therefore, the development of financial performance will make the high rate of return that will be earned by the investor. Return obtained can be in the form of capital gains or dividends. It means that the financial performance affects the firm value.

The statement is supported by Mulyawati et al. (2015), Asiri \& Hameed (2014) and Hidayah (2014), who found evidence that financial performance in this case ROA affects firm value. Based on the description and empirical evidence that has been found, the hypothesis proposed is:

$\mathrm{H}_{2}$ : financial performance has significant effect on firm value.

\section{Effect of Audit Delay on Firm Value}

Delay of financial statement delivery makes delay in decision making by stakeholders. For stakeholders the timeliness of financial statement is very important as it relates to decision making. If delay of financial statement delivery occurs, it will have an impact on the lack of stakeholders trust and make investors shift their views. The consequence is a decline in reputation and firm value. The argument is consistent with the research finding of Asthana (2014) that found evidence that audit delay will give a bad signal to the earnings quality that affects the firm value. Based on the description and empirical evidence, the hypothesis proposed is:

$\mathrm{H}_{3}$ : audit delay has a significant effect on the firm value.

\section{METHOD}

All companies listed in BEI in the period of 2011-2013 were as the population in this study. The purposive sampling method was used in sampling, in order to obtain a representative sample in ac- 
cordance with the criteria specified. Sample criteria used in this research were: (1) the company including banking sector was listed in BEI period 2011-2013, (2) the company published independent auditor report in annual report, (3) it used rupiah exchange rate and (4) it has complete data associated with the variables used in the study.

\section{Definition of Operational and Measurement Variables}

Definitions of operational variables in this study were as follows: (1) financial performance (ROA) became one of the indicators in measuring financial performance. ROA was a ratio that measured the capital invested in an asset as a whole to generate profits for business owners (Gamayuni, 2015). (2) Audit Delay (AD) was a delay in the delivery of financial statement submitted by auditors to issuers or public companies. The measurement in this study used the day scale calculated since the number of days elapsed from the accounting closing period until the audit report date was published (Vuko \& Cular, 2014). (3) Firm Value (VALUE) was measured by the amount of dividend value. Dividend was the profit sharing ratio distributed to shareholders, (Gamayuni, 2015).

\section{Data Analysis Technique}

Multiple linear regression analysis was a statistical analysis technique used in this study. This analysis technique was chosen because it could test the influence of dependent variable and independent variable. There were three models of testing in this study, namely: testing the influence of ROA on $\mathrm{AD}$, testing the effect of ROA on VALUE and testing AD on VALUE.

\section{RESULT}

The data presented in Indonesia Capital Market Directory (ICMD) 2014 showed that there were 496 companies listed in Indonesia Stock Exchange, which consisted of 77 companies in the financial sector and 419 companies in the non-financial sector. This study used a sample of the banking sector companies listed in the Indonesia Stock Exchange. Selection of the samples in this study used purposive sampling. The following is the data of the sample indicated on Table 3.

Table 2. Measurement Variable

\begin{tabular}{|c|c|c|c|}
\hline \multicolumn{4}{|c|}{ Financial performance } \\
\hline $\mathrm{ROA}$ & $\begin{array}{l}\text { Return on } \\
\text { Assets (ROA) }\end{array}$ & $\begin{array}{l}\text { Net After - Tax Provit } \\
\text { Total Assets }\end{array}$ & Gamayuni (2015) \\
\hline \multicolumn{4}{|c|}{ Audit Delay } \\
\hline $\mathrm{AD}$ & Day Calculation & $\begin{array}{l}\text { Date of Audit Report - Date of Accounting } \\
\text { Closing }\end{array}$ & Vuko \& Cular (2014) \\
\hline \multicolumn{4}{|c|}{ Firm value } \\
\hline VALUE & $\begin{array}{l}\text { Dividend } \\
\text { Payout Ratio }\end{array}$ & $\begin{array}{l}\text { Dividend per share } \\
\text { Earnings per share }\end{array}$ & Gamayuni (2015) \\
\hline
\end{tabular}

Table 3. Research Sample

\begin{tabular}{lc}
\hline \multicolumn{1}{c}{ Information } & Number \\
\hline Banking Sector Companies listed in BEI & 38 \\
The number of observation data for 3 years $(38 \times 3)$ & 114 \\
Incomplete data & $(17)$ \\
Total of company data (annual report) & 97 \\
\hline Source: ICMD, 2014 &
\end{tabular}




\section{Testing Result of ROA Effect on Audit Delay}

The result of statistical test showed that financial performance variable had negative coefficient. It meant that financial performance improvement would reduce the occurrence of audit delay.

It can be seen in Table 4 the adjusted value of $\mathrm{R}^{2}$ was 0.145 . It meant that $14.5 \%$ audit delay could be explained by financial performance, while the remaining namely $85.5 \%$ was explained by other variables outside the model. In addition to the adjusted $\mathrm{R}^{2}$, Table 4 also showed $\mathrm{F}$ value of 17.318 with a probability of 0.000 . Similarly, $t$ test showed the same thing. It was got $\mathrm{T}$ arithmetic value of 4.162 with probability level of 0.000 . The probability number was less than 0.05 , thus Ho was rejected. It meant that financial performance affected the occurrence of audit delay. Meanwhile, the beta value was seen at -4.823 , which meant $\beta$ was less than 0 . It indicated that financial performance negatively affected audit delay.

\section{Testing Result of ROA Effect on Firm Value}

The result of statistical test showed that the financial performance variable had a positive co- efficient. It meant that financial performance improvement would increase the firm value. Based on hypothesis testing that had been done, it was obtained that Adjusted $\mathrm{R}^{2}$ value was 0.116 . It meant that $11.6 \%$ of firm value could be explained by the firm performance, while the remaining namely $88.4 \%$ was explained by other factors outside the model. It could be seen that the $\mathrm{F}$ arithmetic value was 13.636 with a probability level of 0.000 . Similarly, the result indicated by the T Test, it was obtained T count of 3.693 with probability level of 0.000 because the probability number was less than 0.05 thus Ho was rejected. It meant that financial performance affected firm value. Meanwhile, the beta value was seen at 4.317 which meant that ? was greater than 0 . It showed that financial performance had a positive effect on firm value.

\section{Testing Result of Audit Delay Effect on Firm Value}

Statistical test result showed that the audit delay variable had a negative coefficient. It meant that the longer audit delay would decrease the firm value.

Table 4. Result of ROA Multiple Linear Regression Analysis on AD

\begin{tabular}{cccccc}
\hline Model & Adjusted R Square & Beta & F & T & Sig. \\
\hline 1 & .145 & -4.823 & 17.318 & -4.162 & $.000(\mathrm{a})$ \\
\hline Dependent variable: Audit Delay & & &
\end{tabular}

Table 5. Result of ROA Multiple Linear Regression Analysis to Firm Value

\begin{tabular}{cccccc}
\hline Model & Adjusted R Square & B eta & F & T & Sig. \\
\hline 1 & 0.116 & 4.317 & 13.636 & 3.693 & $0.00(\mathrm{a})$ \\
\hline Dependent variable: VALUE
\end{tabular}

Table 6. Result of AD Multiple Linear Regression Analysis on VALUE

\begin{tabular}{cccccc}
\hline Model & Adjusted R Square & Beta & F & T & Sig. \\
\hline 1 & .009 & -.140 & 1.919 & -1.385 & $.169(\mathrm{a})$ \\
\hline
\end{tabular}

Dependent variable: VALUE 
It can be seen in Table 6 that the adjusted $\mathrm{R}^{2}$ was at 0,009 . It meant $0,9 \%$ of the firm value could be explained by the audit delay, while the remaining namely $91.1 \%$ was explained by other variables outside the model. Besides adjusted $\mathrm{R}^{2}$ value, Table 6 also showed calculated $F$ value of 1,919 with probability of 0,169 . Similarly, $t$ test showed the same thing. It was got the $t$ arithmetic value of -1.385 with probability level of 0.169 . The probability number was greater than 0.05 , thus Ho was accepted. It meant that audit delay did not affect the firm value. Meanwhile, beta value was seen as $-0,140$ which meant that ? was less than 0 . It indicated that audit delay negatively affected firm value.

The third hypothesis in this study had not been able to prove that audit delay variable significantly influenced the firm value. This could be seen from the result of multiple regression analysis, as shown in Table 6. The result of this study was not in accordance with the expectation of research, and it meant the longer occurrence of company audit delay would reduce the firm value because the timeliness was needed so much by the investors to make investment decisions. Here is a picture of the research with three models:

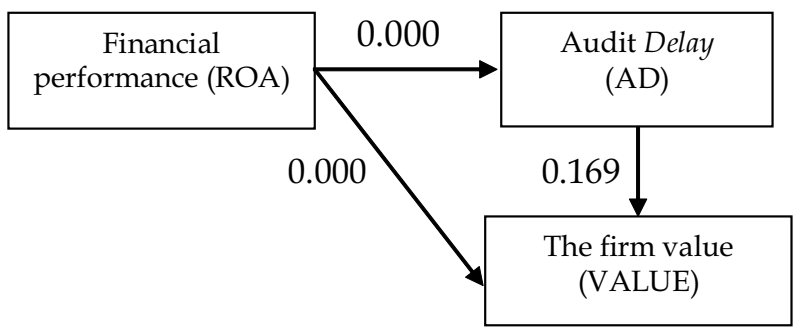

Figure 1. Result of Three Models - Research

\section{DISCUSSION}

The finding of research result on the first hypothesis showed that the financial performance variable had a significant negative effect on audit delay. It could be seen from the results of multiple regression analysis, as shown in Table 4 . The result of this study was in accordance with the research expectations, and it meant that the more the increase of financial performance of the company was, the shorter the occurrence of audit delay was. Companies that generated profit, in this case ROA would immediately inform the public, so audit delay would tend to be shorter. If the companies did not generate profit (loss) then audit delay would tend to be longer because the companies would delay the bad news information (Kartika, 2011). The result of this study was consistent with the researches done by Vuko \& Cular (2014), and Lestari \& Misdiyono (2013) who found evidence that ROA had an effect on audit delay. However, the result of this study was not in accordance with the researches conducted by Hersugondo \& Andi (2013), and Kartika (2011) who found evidence that ROA had no effect on audit delay.

Analyzing the financial performance effect on the firm value was one of the goals of this research. The result showed that the financial performance variable had significant positive effect on firm value. Research evidence was presented in Table 5 which could answer the research objectives. It meant that the more the company financial performance increased, the more the firm value increased. Companies that generated profits, in this case ROA would immediately inform the public, so the firm value would tend to increase. Vice versa if the companies did not generate profit (loss), the firm value would tend to decline because the company would delay the bad news information (Kartika, 2011). This study's findings were in line with researches conducted by Hidayah (2014) and Asiri \& Hameed (2014). However, the results were not in line with research conducted by Tjandrakirana \& Monika (2014). 


\section{CONCLUSION AND SUGGESTION}

\section{Conclusion}

The conclusion of this study is that the better the company financial performance is, the shorter the audit delay will be because the company will soon announce the results of the financial performance to the public, and it will shorten the occurrence of audit delay. Conversely, the better the company financial performance is, the more increasing the firm value is because the company will immediately inform the performance to the public so that public confidence to the company is increasing, and it will impact on the firm value. Audit delay does not have significant effect on firm value. It means this research has not been able to prove the research hypothesis.

\section{Suggestion}

The result of this research can give contribution of thought for the development of science related to financial performance, audit delay, and firm value, so the suggestion that can be given for the development of science through this research is to strengthen the regulation concerning the delivery of financial report in order to increase trust of stakeholders in investment decision making. The practical suggestion of the results of this study is that delay in the delivery of financial statement can reduce public confidence to the company, and it has an impact on the reduction of corporate image in front of the stakeholders. Meanwhile, the suggestions for future researches are to use different research objects, extend the observation time of the study and use other variables that may affect the variables used in the three test models, such as corporate governance mechanism, firm size, government regulation, and so forth.

\section{REFERENCES}

Asiri, B.K., Hameed, S.A. 2014. Financial Ratios and Firm's Value in the Bahrain Bourse. Research Journal of Finance and Accounting, 5(7).

Asthana, Sharad. 2014. Abnormal Audit Delays, Earnings Quality and Firm Value in the USA. Journal of Financial Reporting and Accounting, 12(1): 21- 44.

Ayemere, I.L. \& Elijah, A. 2015. Corporate Attributes and Audit Delay in Emerging Markets: Empirical Evidence from Nigeria. International Journal of Business and Social Research, 05(03): 01-10.

Bank Indonesia. 2012. Peraturan Nomor 14/14/PBI/ 2012 tentang Transparasi dan Publikasi Laporan Bank. Jakarta: Bank Indonesia.

BAPEPAM-LK. 2012. Peraturan Bapepam X.K.6 (Lampiran Keputusan KetuaBapepam Nomor Kep-431/BL/2012 tanggal 1 Agustus 2012). PenyampaianLaporan Tahunan Emiten atau Perusahaan Publik. Jakarta: Badan Pengawas Pasar Modal dan Lembaga Keuangan.

Bursa Efek Jakarta. 2004. Keputusan Direksi PT Bursa Efek Jakarta Kep-307/BEJ/07-2004 tentang Peraturan Nomor I-H tentang Sanksi. Jakarta: Bursa Efek Jakarta.

Connelly, B.L., Certo, S.T., Ireland, R. D., \& Reutzel, C.R. 2011. Signalling Theory: a Review and Assesment. Journal of Management 37(1): 39-67.

Gamayuni, R.R. 2015. The Effect of Intangible Asset, Financial Performance and Financial Policies on the Firm Value. International Journal of Scientific $\mathcal{E}$ Technology Research, 4(01); 202-212.

Hersugondo \& Kartika, A. 2013. Prediksi Probabilitas Audit Delay dan Faktor Determinannya. Jurnal Ekonomi Manajemen dan Akuntansi, XX(35).

Hidayah, N. 2014. The Effect of Company Characteristic toward Firm Value in the Property and Real Estate Company in Indonesia Stock Exchange. International Journal of Business, Economics and Law, 5(1):

Hossain, M.A. \& Taylor, P.J. 1998. An Examination of Audit Delay: Evidence from Pakistan. Papers 64 for APIRA 98 in Osaka, 1-16. 


\section{Jurnal Keuangan dan Perbankan | PERBANKAN}

Vol. 21, No. 2, April 2017: 312-320

Kartika, A. 2011. Faktor-Faktor yang Mempengaruhi Audit Delay pada Perusahaan Manufaktur yang Terdaftar di BEI. Dinamika Keuangan dan Perbankan, 3(2): 152-171.

Lawrence, J. \& Bryan, B. 1998. Characteristics Associated with Audit Delay in the Monitoring of Low Income Housing Projects. Journal of Public Budgeting Accounting E Financial Management, 10(2): 173191.

Lestari, L.A. \& Misdiyono. 2013. The Influence of the Internal Factor and External against Audit Delay on Banking Industry in Indonesia Stock Exchange. Jurnal Ekonomi dan Kewirausahaan, 9(18): 31-41.

Mulyawati, S., Rini, L., \& Nurleli. 2015. Pengaruh Kinerja Keuangan terhadap Nilai Perusahaan. Prosiding. Penelitian SPeSIA.

Otoritas Jasa Keuangan. 2014. Surat Edaran Nomor 11/ SEOJK.04/2014 tentang Kewajiban Penyampaian Laporan kepada OJK. Jakarta: Otoritas Jasa Keuangan.
Otoritas Jasa Keuangan. 2015. Peraturan Otoritas Jasa Keuangan Nomor 6/POJK.03/2015 tentang Transparansi dan Publikasi Laporan Bank. Jakarta: Otoritas Jasa Keuangan.

Sutinen, J.G. \& Kuperan. K. 1999. A Socio Economic Theory of Regulatory Compliance. International Journal of Social Economics, 26: 174-193.

Tjandrakirana, R. \& Monika, M. 2014. Pengaruh Kinerja Keuangan Terhadap Nilai Perusahaan Pada Perusahaan Manufaktur yang Terdaftar di Bursa Efek Indonesia. Jurnal Manajemen E Bisnis Sriwijaya 12(1).

Vuko, T. \& Cular, M. 2014. Finding Determinants of Audit Delay by Pooled OLS Regression Analysis. Croatian Operational Research Review, 5(2014): 8191. 